\title{
Transformation of Pesantren Persatuan Islam
}

\author{
A. Rofik Husen*, Danny Meirawan \\ Department Education Administration \\ Universitas Pendidikan Indonesia \\ Bandung, Indonesia \\ *rofikhusen@upi.edu
}

\begin{abstract}
Law No 18 of 2019 on Pesantren becomes initial milestones for the institutional formulation of Pesantren (Islamic boarding school) in Indonesia. This law ratifies a pesantren as a part of national education systems after several decades as a nonformal educational institution. Consequently, it needs many requirements for graduation to have legality from the government. "Pesantren Persatuan Islam" as one of an educational institution established in Bandung since 1936 which currently has more than 300 institutions spreading to several regions in Indonesia. Initially, "Pesantren Persatuan Islam" was a general Islamic Boarding School in Indonesia. However, the enactment Law No. 20 of 2003 on National Education System compels most of the pesantren to adapt the implemented regulation. Subsequently, it transforms an Islamic School and Formal School having formal legislation. This writing aims to give an alternative solution for Persatuan Islam Organization responding the enactment Law No. 18 of 2019 on Pesantren to continually contribute on Islamic Educational Realm in Indonesia in particular and Muslim in general.
\end{abstract}

Keywords-Pesantren, Islamic boarding school, Persatuan Islam, Persis, Pesantren transformation

\section{INTRODUCTION}

Law No. 18 of 2019 states Pesantren is a community basedinstitution which one of the aims is to develop the individual to become a religious expert. Developing the individual, Pesantren has at least three functions such as education, Islamic missionary work/dakwah, and community development [1].

Generally, Pesantren is created by an individual or group initiative to change society and culture order in a region using a religious approach. Therefore, the existing Pesantren will bring distinctive character based on a founder, location, and sociocultural condition in that community. Yasid states Pesantren must have its uniqueness which is different from the other educational institutions. One of the unique things is a system which obtains the value by accessing religious teachings through yellow book literature [2].

Mastukki [3] describes pesantren in Indonesia had just been recognised by people since 16th century. It was described in classic work by Serat Sentini who illustrated Indonesia had many institutions which taught a classic book in fiqh, faith, and Sufism and had a function as a place for Islamic propagation. The name of "pesantren" (Islamic boarding school) is generally used in Jawa, but another name which allied with it such as "surau" in West Sumatra, "dayah" in Aceh, and "langgar" in South Sumatera.

Several reputable Islamic boarding schools become a place for learning Islam not only for Indonesian citizen but also from other countries. This fact proves that the uniqueness of learning pattern conducted in Islamic boarding school can reduce cultural barrier and state boundaries.

\section{Government Regulation Regarding PESAntren}

Before the enactment of Law No. 18 of 2019, as an independent educational institution, Pesantren in Indonesia consists of various formats in terms of legality, management and graduation procedure. It relates to Nurcholis describes the Islamic boarding school is an artefact established as a devout educational institution having a traditional, unique and indigenous pattern.

Moreover, Nurcholis Madjid states pesantren has historical relation with pre-Islam institutions which were existed since Buddhist-Hindu Kingdoms. Therefore, pesantren must continue it through Islamization using all adjustments and changes [3].

Diversity on pesantren as background, the enactment Law No. 18 of 2019 attempts to embrace all various pesantren becomes a part of a national education system and at the same time as state recognition of the existing Islamic boarding school all this time.

Several things have been regulated in this law. The Pesantren has three kinds such as teaching a student to review the yellow book, "Muallimin" pattern and integrating its learning process with general education.

In order to be recognised as the Pesantren, it must have these elements, including:

- "kyai" (people who are expert in Islam);

- "santri” (student);

- “pondok" (dormitory);

- "masjid / musholla" (mosque); 
- Recitation or study the yellow book (dirasah Islamiyah) with missionary education pattern (mu'allimin).

In verse 15 Law No. 18 of 2019 stated pesantren carries out educational function as the part of national education implementation. Then, in the next verse, it is stated pesantren also carries out Islamic missionary work (dakwah) function to create Islam as "rahmatan lil "alamin" grace to the universe. Lastly, pesantren has community development function which has orientation on the improvement of Islamic boarding school and community wealth.

As for an Islamic school and formal school, the government has already regulated in national education law which is Law No. 20 of 2003 on National Education System [4].

\section{ISLAMIC UNITY PESANTREN}

As the Pesantren in general, the initial aim to create "Persatuan Islam" Islamic Boarding School in Bahasa Pesantren Persatuan Islam (Persis) which is stated by Rosyidin in order to deepen the study of Islam to develop preacher candidate expected in the future can spread and teach Islam as "Pesantren Persatuan Islam" understanding [5].

Pesantren Persatuan Islam was firstly built in Bandung 1936 by A. Hassan, a teacher of "Persatuan Islam" then expanded to all Indonesia regions divided into several paths, grades and kinds of education [6].

A characteristic of "Persatuan Islam" in giving the name of all educational institutions under this organisation is the name of "Pesantren Persatuan Islam (PPI)" as the central institution for various kinds of the established educational institution including general schools such as elementary school, junior high school, senior high school, vocational school and Islamic school such as Islamic elementary school (madrasah ibtidaiyah/MI), Islamic junior high school (madrasah tsanawiyah/MTs), Islamic senior high school (madrasah aliyah/MA). All these kinds of school are under the name of "Pesantren Persatuan Islam (PPI)".

Currently, the educational institution having the name of "Pesantren Persatuan Islam (PPI)" is recorded about 335 institutions throughout Indonesia. Mostly are located in West Java. Based on data obtained Persis Education Development Department [7], in West Java has more than 275 Islamic boarding schools with various levels including 37 Islamic Elementary Schools, 88 Islamic Junior High Schools, 53 Islamic Senior High Schools, 23 Elementary Schools, 15 Junior High School, 4 Senior High Schools, 4 Vocational Schools and hundreds of Diniyah which are existed in every "Persatuan Islam" community.

This potency will be continually developed under several reasons, including:

- Indonesian demographic bonus which certainly needs a qualified Islamic educational institution facing global competition.
- Loyalty and militancy "Persatuan Islam" cadres who are ready to fight with all they have for their faith (Islam) based on Holy Quran and As-Sunnah.

- "Persis" educational concept is unique and adaptive with the change. "Persis" curriculum is al-ways updated along with technological developments.

This potency will be developed if the head of "persis" central organization as the only institution which controls all authorities on "persis" education regulation can create a grand design for organised education and not only to achieve organisation goals but also to give significant contribution for Islamic education development in Indonesia particularly and Islamic realm in general.

Before the enactment of Law No. 18 of 2019, as an independent educational institution, Pesantren in Indonesia consists of various formats in terms of legality, management and graduation procedure. It relates to Nurcholis Madjid's statement quoted from a book titled Islamic school and Islamic boarding school synergy. He describes the Islamic boarding school is an artefact established as a devout educational institution having a traditional, unique and indigenous pattern.

\section{TRANSFORMATION OF PESANTREN PERSATUAN ISLAM}

Law No. 18 of 2019 on pesantren principally completes regulations which are existed in Law No. 20 of 2003 on National Education System. For independent Islamic boarding school which do not use Law No. 20 of 2003 as a reference on its institution management, the enactment Law No. 18 of 2019 is the most awaited answer from the government. Therefore, the enactment of this law is greeted with joy. Combining an education model in Law No. 20 of 2003 such as formal school and Islamic school with the model in Law No. 18 of 2019 such as Islamic boarding school, hence, there are three educational institution models in Indonesia including formal school, Islamic school and Islamic boarding school.

The problem is occurred for Islamic boarding school due to the need of graduation legality decides to adopt Law No. 20 of 2003 by changing the nomenclature of their education unit to become Islamic school following this regulation. The enactment Law No. 18 of 2019 makes the Islamic boarding school facing difficulty because this law makes a clear concept that Islamic boarding school has five elements such as "kyai" (people who are expert in Islam), "santri" (student), "masjid" (mosque), boarding house and study of the yellow book using salafiyah and dirosah/mua'llimin learning method. Therefore, it is crystal clear that Islamic school is not part of an educational pattern in the Islamic boarding school. Besides, this transformed Islamic school had an initial aim to create the Islamic boarding school but changes to Islamic school due to legality aspect.

In general, Pesantren Persatuan Islam has the same turmoil with the transformed Islamic boarding school and changes to the Islamic school and formal school. This condition happens because even though institution name using the name of 
Islamic boarding school, however, in a formal juridical and all regulation use the regulation regarding Islamic school and general school as regulated in Law No. 20 of 2003.

The educational institution in "Persatuan Islam" organisation stated in the previous section consists of Islamic and formal school. The Islamic school in "Persatuan Islam" includes Islamic elementary school (madrasah ibtidaiyah/MI), Islamic junior high school (madrasah tsanawiyah/MTs), Islamic senior high school (madrasah aliyah/MA) and Islamic School of Diniyah Ula or Diniyah Takmiliyah. Other kinds are the elementary school, junior high school, senior high school, and vocational school.

"Pesantren Persatuan Islam (PPI)" which is under the Ministry of Religious Affairs has al-most $90 \%$ from the existing PPI. It is clear due to a historic reason and similarity in the educational goals under the Ministry of Religious Affairs such as Islamic elementary school (madrasah ibtidaiyah/MI), Islamic junior high school (madrasah tsanawiyah/MTs), Islamic senior high school (madrasah aliyah/MA) have learning process focussing the Islamic education from all aspects.

The rest $10 \%$ of educational institutions which are under the Ministry of Education and Culture include elementary school, junior high school, senior high school, and vocational school. The learning focus is different between educational institutions under the Ministry of Religious Affairs and the Ministry of Education and Culture. In the Ministry of Education and Culture, Islamic subject is just a part of the learning process, not the main goal.

Based on the conducted observation, "Persatuan Islam" currently does not have any formal institution as Islamic boarding school regulated in Law No. 18 of 2019 because this institution consists of more than 300 institutions which are more accurately called as the Islamic school and formal school rather than Islamic boarding school despite several institutions are fulfilling the requirement to be recognised as Islamic boarding school as regulated in the law. These institutions are Persis 67 Benda Tasikmalaya, Persis 50 Lembang and other Persis institutions which have full boarding school concept, but formally these institutions are recorded as Islamic school which have boarding house. Currently, "Persatuan Islam" Islamic boarding school has two from three kinds of the existing educational institution. The first kind is an education unit of Islamic elementary school (madrasah ibtidaiyah/MI), Islamic junior high school (madrasah tsanawiyah/MTs), Islamic senior high school (madrasah aliyah/MA) and Islamic School of Diniyah Ula or Diniyah Takmiliyah under the Ministry of Religious Affairs then the education unit of elementary school, junior high school, senior high school, and vocational school under the Ministry of Education and Culture. Considering the initial goal of the establishment "Persatuan Islam" Islamic boarding school is to develop Persis's cadres who understands religion and becomes preachers who are capable of broadcasting, teaching and defending Islam wherever they are. Therefore, this type of educational institution is more suitable in Islamic boarding school format because it gives freedom of expression for "Persatuan Islam" Islamic boarding school to develop all education concepts related with the identity when was created. This educational concept is not constrained by the rules that bind strictly as the currently applied rules.

This writing proposes for "Persatuan Islam" Islamic boarding school can have three kinds of education related to the law such as general school, Islamic school and Islamic boarding school without change the existing educational institutions. We can create it by changing the nomenclature on all "Persis" educational institutions following the applied regulations. The proposed solutions are including:

- For educational institutions such as Islamic Elementary School (Madrasah Ibtidaiyah/MI), Islamic Junior High School (Madrasah Tsanawiyah/MTs), Islamic Senior High School (Madrasah Aliyah/MA) which are under the Ministry of Religious Affairs should change the name becoming Persatuan Islam Integrated Islamic School or "Madrasah Terpadu Persatuan Islam (MTPI)" both for institutions which have boarding house or not [8].

- Elementary school, junior high school, senior high school, and vocational school which are under the Ministry of Education and Culture should not use the name of "Persatuan Islam" Islamic boarding school anymore as its main institution because the establishment is different to Islamic boarding school. The proposed name for the institution which controls all general schools is "Per-satuan Islam" integrated school or "Sekolah Terpadu Persatuan Islam (STPI)" both for institutions which have boarding house or not.

- The establishment of a new institution in form of "Persatuan Islam" Islamic boarding school or Pesantren Persatuan Islam (PPI) uses the name of Kulliyatul Mu'allimin Al Islamiyah (KMI), Madrasah Mu'allimin Al Islamiyah (MMI), Tarbiyatul Mu'allimin Al Islamiyah (TMI) or any name agreed as the educational institution which aims to create Persis's cadres by giving the most of learning portion on yellow book study. The curriculum used in this institution can adopt the earlier curriculum which was ever adopted in the first of PPI establishment in 1936 or compelling curriculum structure adjusted with current needs.

The offered institutions are indeed more numerous than now which is only one institution by the name of "Pesantren Persatuan Islam (PPI)", however, this will ease and make organization more focus to manage because each education type has different goals and policies.

Some parties want the existing educational institution in Persis to completely transform and adopt the regulation in Law No. 18 of 2019. However, in writer opinion, it will be tricky to be done for the following reasons:

- It is not easy to change the organisational culture which is existing for a long period in a short time. The best 
course is by allowing the old institution to continue developing and establish a new institution using a new culture, format and goal.

- The processes of accreditation, certification, various stages have been done by educational institutions of the existing Persis to be recognized by the state and accepted by the community. Leaving all of that behind and replacing with a new regulation which has not yet been published will be a very difficult step to take, particularly if it is related to the various received conveniences and facilities. Therefore, the solution is to let the current educational institutions still exist to be continually established and developed. As for the institutions which will be created have to follow the pattern of Islamic boarding school determined by organisations.

The Islamic boarding school model with the concept of mua'llimin as regulated in Law No. 18 of 2019 when it is compared with yellow book study model should be a new alternative in establishing education institution in Persis organisation apart from Islamic school and general school as it is already existing because the mu'allimin concept as regulated in the law gives full freedom to administrators providing subject materials related with organisation goals.

Ultimately, Persatuan Islam organisation has three institutional paths consisted of Islamic boarding school, Islamic school and formal school which run simultaneously filling the various existing line. Therefore, there is no reason for the organisation lack of cadres because the process of cadres developing has been done in all available lines. It remains only to continually strengthen, direct and guide them so the cadres can provide optimal benefits to the organisation which develop them.

\section{CONCLUSION}

The future of Islam particularly and human civilisation generally are influenced by the quality of the existing education. If education today is developed on a strong foundation such as religious values, truth, science, honesty, improvement spirit and all the other positive thing, human civilisation will be better rather than today. However, if the foundation is established on hatred, intolerance, hostility, and various negative things, the human civilisation will destruct, referring to Islamic literature, then doomsday will happen.

"Persatuan Islam" Islamic boarding school is the educational institution model which is proved can survive since the first establishment in 1936 and produce the graduation spread all corners of the archipelago and give birth to the new student of Persis. It proves that the concept of "Persatuan Islam" Islamic boarding school has been tested. However, as the law changes, it is necessary to think about regulation of the existing educational institution and create rules for the unestablished institutions according to rules and regulations which apply in this beloved country.

\section{REFERENCES}

[1] UU Republik Indonesia No 18 Tahun 2019 tentang Pesantren.

[2] A. Yasid, "Paradigma Baru Pesantren: Menuju Pendidikan Islam Transformatif," IRCISoD, 2018

[3] Mastukki dan A. Adhim, Sinergi Madrasah dan Pondok Pesantren: Suatu Konsep Pengembangan Mutu Madrasah. Jakarta: Departemen Agama RI Direktorat Jenderal Kelembagaan Agama Islam, 2004.

[4] UU Republik Indonesia No 20 tahun 2003 tentang Sistem Pendidikan Nasional.

[5] D. Rosyidin, Konsep Pendidikan Formal Islam: Ikhtiar Pendidikan Formal Persis Dalam Mencetak Generasi Tafaqquh Fiddin. Pustaka Nadwah, 2009.

[6] Qanun Asasi dan Qanun Dakhili Persatuan Islam, Masa Jihad 2015 2020

[7] Data Pendidikan Persatuan Islam Jawa Barat, 2020.

[8] U. Umar, Manajemen Madrasah Bermutu: Madrasah Lebih Baik, Lebih Baik Madrasah, Pustaka Rahmat, 2016. 